\title{
Decreased H2 Histamine Response of Granulocytes
}

\section{of Asthmatic Patients}

\author{
William W. Busse and JefFrey Sosman \\ From the Department of Medicine, University of Wisconsin Medical School, \\ Madison, Wisconsin 53706
}

A B S T RACT Increased bronchial sensitivity to inhaled histamine in asthma is well known. The mechanism of this increased bronchial sensitivity is not known nor has it been demonstrated that isolated cells respond abnormally to histamine. Polymorphonuclear leukocytes (PMNs) provide a homogeneous cell population to study agonist response. Release of granulocyte lysosomal enzymes is inhibited by agonists increasing the PMN cyclic AMP concentration. The release of the lysosomal enzyme beta glucuronidase by serum-activated particles of zymosan was similar in PMNs isolated from normal and asthma subjects. Histamine (100-0.01 $\mu \mathrm{M})$ inhibited enzyme release. Except at the maximal concentration of histamine $(100 \mu \mathrm{M})$, the response to histamine was decreased in asthma. The inhibition of enzyme release paralleled an increase in intracellular PMN cyclic AMP. In asthma, the cyclic AMP response to histamine was reduced. The $\mathrm{H} 2$ antihistamine metiamide blocked histamine inhibition of lysosomal enzyme release and the increase in cyclic AMP. The effect was maximal at concentrations equimolar to those of histamine. The $\mathrm{H} 1$ antihistamine chlorpheniramine had no effect on histamine inhibition of granulocyte lysosomal enzyme release. A decrease in the inhibition of the release of the inflammatory lysosomal enzymes from granulocytes in asthma may contribute to an enhanced bronchial inflammatory reaction.

\section{INTRODUCTION}

Asthma is characterized by excessive irritability of the airways. In asthma, vigorous bronchoconstriction follows inhalation of histamine (1), acetylcholine (2), prostaglandin $F_{2 \alpha}(3)$, and irritants (4). Enhanced bronchoconstriction to histamine is of special interest

\footnotetext{
Presented in part at the American Academy of Allergy meeting, 6-10 March 1976 in San Juan, Puerto Rico.

Received for publication 13 October 1976 and in revised form 4 February 1977.
}

in view of its role as a mediator in IgE-mediated allergic asthma. Increased bronchial sensitivity to histamine in mice follows vaccination with Bordetella pertussis organisms (5). B. pertussis-treated mice also have a decrease in the beta-adrenergic response (6). These observations lead to the proposal that increased airway sensitivity found in asthma to various stimuli, such as histamine, was the result of diminished betaadrenergic response (7). It was also hypothesized that decreased beta-adrenergic response in asthma was not limited to the airways but a generalized phenomenon. Both in vivo and in vitro studies with isolated tissues have found decreased beta-adrenergic response in asthma (8-12). However, an altered response to histamine in isolated tissue has not yet been described in asthma (13).

Studies from many laboratories have confirmed the existence, originally proposed by Ash and Schild (14), that at least two types of histamine receptors were involved in the histamine response. $\mathrm{Hl}$ histamine receptor responses include vasodilation and smooth muscle contraction specifically blocked by the antihistamines mepyramine, diphenhydramine, and chlorpheniramine. $\mathrm{H} 2$ responses involve gastric acid secretion, rat uterine muscle relaxation, and guinea pig atrium contraction which are not blocked by the above antihistamines. Confirming the presence of H2 histamine receptors was possible with the discovery of new antagonists, burimamide, metiamide, and cimetidine, which specifically block the second group of responses to histamine, but not the first (15).

Polymorphonuclear leukocyte $(\mathrm{PMNs})^{1}$ provide a homogeneous cell population for in vitro studies of responses to agonists in asthma (16). Release of inflammatory lysosomal enzymes from granulocytes follows phagocytosis, which is conveniently investi-

\footnotetext{
${ }^{1}$ Abbreviations used in this paper: BG, beta glucuronidase; cAMP, cyclic AMP; CB, cytochalasin B: HBSS, Hanks' balanced salt solution; PMNs, polymorphonuclear leukocytes.
} 
TABLE I

Clinical Characteristics of the Subjects with Asthma

\begin{tabular}{|c|c|c|c|c|c|}
\hline \multirow{2}{*}{$\begin{array}{l}\text { Patient } \\
\text { number }\end{array}$} & \multirow[b]{2}{*}{ Sex } & \multirow[b]{2}{*}{ Age } & \multirow[b]{2}{*}{ Severity } & \multicolumn{2}{|c|}{ Medication } \\
\hline & & & & Current & Prior* \\
\hline & & $y r$ & & & \\
\hline 1 & $\mathbf{M}$ & 33 & Mild & None & Aminophylline \\
\hline 2 & $\mathbf{M}$ & 35 & Moderate & Aminophylline & \\
\hline 3 & $\mathrm{~F}$ & 34 & Moderate & Aminophylline & \\
\hline 4 & $\mathbf{F}$ & 33 & Mild & None & Aminophylline and ephedrine \\
\hline 5 & $\mathrm{~F}$ & 59 & Moderate & Aminophylline & \\
\hline 6 & $\mathbf{F}$ & 60 & Moderately severe & $\begin{array}{l}\text { Aminophylline } \\
\text { Prednisone (alternate days) }\end{array}$ & \\
\hline 7 & $\mathbf{F}$ & 37 & Moderate & Aminophylline & \\
\hline 8 & $\mathbf{M}$ & 41 & Mild & None & Aminophylline \\
\hline 9 & $\mathbf{M}$ & 27 & Mild & None & Aminophylline \\
\hline 10 & $\mathbf{M}$ & 31 & Mild & None & Aminophylline \\
\hline 11 & $\mathrm{~F}$ & 25 & Moderate & Aminophylline & \\
\hline 12 & $\mathbf{M}$ & 32 & Moderately severe & $\begin{array}{l}\text { Aminophylline } \\
\text { Prednisone (alternate days) }\end{array}$ & \\
\hline 13 & $\mathbf{F}$ & 28 & Mild & None & Aminophylline \\
\hline 14 & M & 28 & Moderate & Aminophylline & \\
\hline 15 & $\mathbf{F}$ & 28 & Mild & None & Aminophylline \\
\hline
\end{tabular}

* The patients had not taken these medications for $2 \mathrm{wk}$ before the studies.

gated in vitro with incubation of granulocytes in the presence of complement activated particles of zymosan $(17,18)$. Modulation of the release of these enzymes follows changes in the concentration of intracellular cyclic nucleotides $(19,20)$. Isoproterenol and prostaglandin $\mathrm{E}_{1}$ inhibit release of lysosomal enzymes apparently by activating adenylate cyclase. Conversely, cholinergic agonists enhance enzyme release that is associated with increases in granulocyte levels of cyclic GMP. Modulation of the lysosomal enzyme release is therefore similar to that of histamine and slow reacting substance of anaphylaxis from mast cells (21), sensitized leukocytes (22), and chopped lung preparations after antigen challenge (23).

We reported that histamine inhibition of serumactivated zymosan-induced lysosomal enzyme release from granulocytes is an $\mathrm{H} 2$ receptor response and parallels increases in intracellular cyclic AMP (24). The following study found the $\mathrm{H} 2$ histamine response of granulocytes from patients with asthma was decreased.

\section{METHODS}

Patient selection. Adult volunteers with asthma were selected for study from the patient population of the University of Wisconsin Allergy and Immunology Clinic. The following data is based upon observations in a total of 15 patients with asthma. The patients ranged in age from 25 to $60 \mathrm{yr}$ with a mean age of $35.4 \mathrm{yr}$. Asthma had been present in the patients for at least $2 \mathrm{yr}$. All have previously demonstrated reversible airway obstruction. At the time of study all patients had active but stable asthma. The clinical characteristics of the 15 asthma patients studied are presented in Table I. The severity of their asthma symptoms is classified as mild, moderate, or moderately severe. Patients with mild asthma had daily symptoms of wheezing or chest tightness that was not to the degree that it required treatment. None of these patients had used any form of bronchodilator therapy for at least $2 \mathrm{wk}$ before study. The subjects with moderate severity of asthma had daily symptoms of asthma requiring routine daily use of bronchodilators (aminophylline). Two subjects were classified as being moderately severe in that they required alternate day prednisone to control their symptoms of asthma. Studies on these patients were not done on the day they had received corticosteroids. Care was also taken that all these patients were not receiving oral antihistamines or any other 
TABLE II

Release of the PMN Lysosomal Enzyme, Beta Glucuronidase, in Normal and Asthma Subjects (Mean \pm SEM)*

\begin{tabular}{|c|c|c|c|}
\hline & \multirow{2}{*}{$\begin{array}{c}\text { Total } \\
\text { enzyme }\end{array}$} & \multicolumn{2}{|c|}{ Enzyme release } \\
\hline & & Resting & Stimulated \\
\hline Normal $(n=9)$ & $67.6 \pm 4.2$ & $2.6 \pm 0.5$ & $21.3 \pm 0.7(32.2 \%) \S$ \\
\hline Asthma $(n=10)$ & $67.8 \pm 2.1$ & $2.7 \pm 1.1$ & $20.9 \pm 1.1(30.8 \%)$ \\
\hline
\end{tabular}

* All incubations at $37^{\circ} \mathrm{C}$. PMNs $\left(3 \times 10^{6} / \mathrm{ml}\right)$ were pretreated with CB $(5 \mu \mathrm{g} / \mathrm{ml}$ for $5 \mathrm{~min})$ before the addition of serum $(0.1 \mathrm{ml})$ and zymosan $(0.1 \mathrm{ml}$ of $10 \mathrm{mg} / \mathrm{ml})$ for $30 \mathrm{~min}$.

$\$$ Micrograms of phenophthalein per $18 \mathrm{~h}$ per $10^{6} \mathrm{PMN}$.

$\S$ Percent of total enzyme released after $30 \mathrm{~min}$ of incubation with zymosan and serum.

medication. The 14 subjects serving as controls did not have a history of asthma or other allergic diseases and ranged in age from 20 to $58 \mathrm{yr}$ with a mean age of $30 \mathrm{yr}$. None of the control subjects were receiving medications at the time of study.

In experiments where neutrophils were obtained from the same subject for different experiments, care was taken that there was no change in medication and that their clinical status of asthma was similar at different study periods.

Cell preparation. Human PMNs were separated from anticoagulated blood, EDTA $(2.7 \%)$, by the method of Böyum (25), and suspended in Hanks' balanced salt solution (HBSS) in a final concentration of $3 \times 10^{6} / \mathrm{ml}$ (98\% PMNs). Replicate samples $\left(3 \times 10^{8} \mathrm{PMNs}\right.$ in $1 \mathrm{ml}$ HBSS $)$ were preincubated at $37^{\circ} \mathrm{C}$ in a shaking water bath for $5 \mathrm{~min}$ with cytochalasin B (CB) before the addition of $0.1 \mathrm{ml}$ fresh autologous serum and $0.1 \mathrm{ml}$ of the prepared zymosan (26). Preincubation of the PMNs with the fungal metabolite $\mathrm{CB}$ prevents phagocytosis of the zymosan particles but not

TABLE III

Percent Inhibition of Beta Glucuronidase Release with Histamine in PMNs from Asthma Subjects

\begin{tabular}{llllllll}
\hline & & \multicolumn{5}{c}{ Histamine, $\mu M$} \\
\cline { 3 - 7 } & Sex & Age & 0.01 & 0.1 & 1.0 & 10 & 100 \\
\hline & $y r$ & & & & &
\end{tabular}

Asthma

\begin{tabular}{clllrrrr} 
patient & & & & & & & \\
1 & M & 33 & 0.0 & 5.5 & 10.0 & 11.8 & 30.9 \\
2 & M & 35 & 0.0 & 0.0 & 9.8 & 15.7 & 19.7 \\
3 & F & 34 & 3.7 & 3.7 & 16.7 & 30.0 & 30.0 \\
4 & F & 33 & 0.0 & 4.4 & 6.1 & 16.6 & 25.3 \\
5 & F & 59 & 0.0 & 2.3 & 9.2 & 12.2 & 22.1 \\
6 & F & 60 & 0.0 & 13.2 & 21.9 & 22.9 & 35.1 \\
7 & F & 37 & 0.0 & 11.1 & 5.4 & 9.7 & 16.2 \\
8 & M & 41 & 0.0 & 1.5 & 5.1 & 16.0 & 26.1 \\
9 & M & 27 & 0.0 & 0.0 & 4.2 & 14.6 & 27.1 \\
10 & M & 31 & $\underline{8.9}$ & $\underline{12.3}$ & $\underline{11.6}$ & 15.7 & 21.8 \\
Mean & & & 1.3 & 5.4 & 10.0 & 16.5 & 25.4 \\
\pm SEM & & & 1.2 & 1.6 & 1.8 & 1.9 & 1.8 \\
\hline
\end{tabular}

lysosomal enzyme release, which is in fact enhanced. The CB-treated PMNs resemble secretory cells. This removes the concern that the agonists may interfere with phagocytosis rather than just enzyme release. Zymosan particles were boiled in saline $(10 \mathrm{mg} / \mathrm{ml})$, washed, and resuspended in HBSS $(10 \mathrm{mg} / \mathrm{ml})$. After a 30 -min incubation at $37^{\circ} \mathrm{C}$, the samples were centrifuged $\left(750 \mathrm{~g}\right.$ for $10 \mathrm{~min}$ at $\left.4^{\circ} \mathrm{C}\right)$ and the cell supernates were removed for enzyme determination. Total enzyme activity was determined after cell lysis with Triton X-100 (Rohm \& Haas Co., Philadelphia, Pa.) (0.2\%).

Pharmacological studies. In testing the effect of histamine on the release of beta glucuronidase (BG), the PMNs were first treated with $C B$ and then incubated with the test compounds. In the following studies duplicate samples were performed at each experimental point. Theophylline $(0.5 \mathrm{mM})$, a concentration insufficient to affect enzyme release by itself, was added and the PMNs were incubated for $15 \mathrm{~min}$ at $37^{\circ} \mathrm{C}$. The cells were then incubated with freshly prepared histamine diphosphate for an additional $15 \mathrm{~min}$ at $37^{\circ} \mathrm{C}$ before the addition of serum and zymosan. After $30 \mathrm{~min}$ of incubation with serum and zymosan, the samples were centrifuged and BG activity was determined in the supernate. The release of $B G$ in the presence of histamine was compared to cells not treated. In the experiments with antihistamines, these drugs were added immediately before histamine.

Enzyme assays. The lysosomal enzyme BG in the supernate was measured after $18 \mathrm{~h}$ of incubation with phenolphthalein glucuronic acid at $37^{\circ} \mathrm{C}$ and expressed as micrograms of phenolphthalein per $10^{6}$ PMN per $18 \mathrm{~h}$ (27). Total PMN enzyme concentration was assayed after cell rupture with $0.2 \%$ Triton $\mathrm{X}-100$. Cell viability was determined by exclusion of trypan blue dye and assaying the concentration of the cytoplasmic enzyme lactate dehydrogenase in the supernate (28). Inhibition of BG release was calculated by comparing the enzyme release after treatment to untreated cells.

Cyclic AMP (cAMP) determinations. Duplicate samples of PMNs $\left(3 \times 10^{6} \mathrm{PMNs} / 1 \mathrm{ml}\right.$ HBSS $)$ were incubated at $37^{\circ} \mathrm{C}$ with theophylline $(0.5 \mathrm{mM}$ for $15 \mathrm{~min})$ before incubating with histamine $(15 \mathrm{~min})$. In experiments with

TABLE IV

Percent Inhibition of Beta Glucuronidase Release with Histamine in PMNs from Normal Subjects

\begin{tabular}{|c|c|c|c|c|c|c|c|}
\hline & \multirow[b]{2}{*}{ Sex } & \multirow[b]{2}{*}{ Age } & \multicolumn{5}{|c|}{ Histamine, $\mu \mathrm{M}$} \\
\hline & & & 0.01 & 0.1 & 1.0 & 10 & 100 \\
\hline & & $y r$ & & & & & \\
\hline \multicolumn{8}{|l|}{$\begin{array}{l}\text { Normal } \\
\text { subjects }\end{array}$} \\
\hline 16 & $\mathbf{M}$ & 34 & 17.3 & 21.4 & 25.5 & 34.7 & 32.7 \\
\hline 17 & $\mathbf{M}$ & 22 & 5.4 & 11.0 & 19.6 & 32.8 & 28.6 \\
\hline 18 & $\mathbf{M}$ & 33 & 10.0 & 13.3 & 14.2 & 24.2 & 29.2 \\
\hline 19 & $\mathbf{M}$ & 31 & 12.4 & 18.6 & 21.7 & 32.0 & 32.9 \\
\hline 20 & $\mathbf{M}$ & 24 & 10.6 & 12.3 & 16.4 & 25.2 & 27.5 \\
\hline 21 & $\mathbf{F}$ & 58 & 5.8 & 8.7 & 18.3 & 29.8 & 28.9 \\
\hline 22 & $\mathbf{F}$ & 20 & 9.2 & 10.9 & 14.2 & 21.7 & 20.0 \\
\hline 23 & $\mathbf{F}$ & 23 & 7.0 & 16.6 & 22.7 & 29.6 & 27.0 \\
\hline 24 & $\mathbf{F}$ & 24 & 8.8 & 11.0 & $\underline{17.6}$ & 21.9 & 24.9 \\
\hline Mean & & & 9.6 & 13.8 & 18.9 & 28.0 & 28.0 \\
\hline \pm SEM & & & 1.2 & 1.4 & 1.3 & 1.6 & 1.3 \\
\hline
\end{tabular}




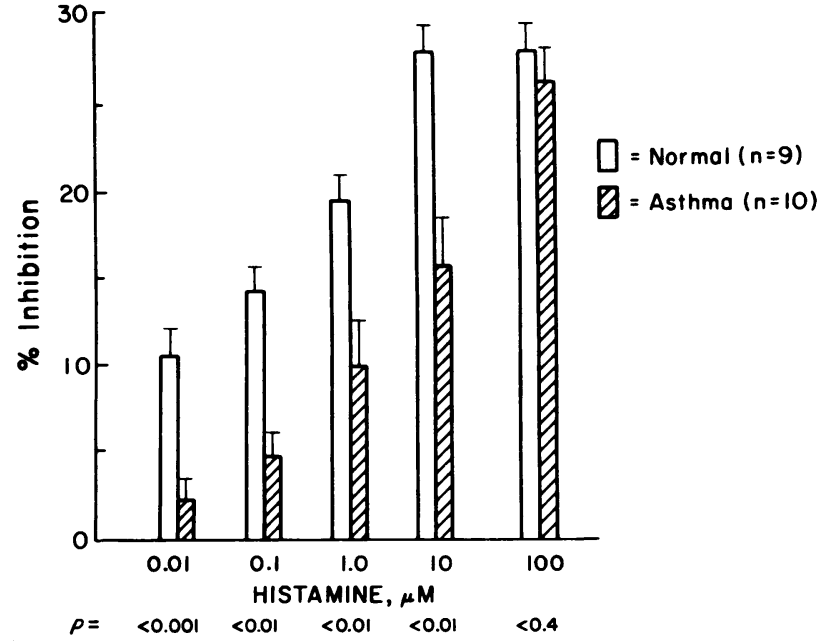

FIGURE 1 Percent inhibition of PMN lysosomal enzyme BG by histamine. PMNs $\left(3 \times 10^{6} / \mathrm{ml}\right)$ were incubated with CB $(5 \mu \mathrm{g} / \mathrm{ml}$ for $5 \mathrm{~min})$ and theophylline $(0.5 \mathrm{mM})$ for $15 \mathrm{~min}$ before the addition of histamine and then incubated for an additional $15 \mathrm{~min}$. The cells were then exposed to serum and zymosan for $30 \mathrm{~min}$. Percent inhibition is calculated by comparing enzyme release of treated to untreated cells. Values are expressed as the mean $\pm \mathrm{SEM}$.

antihistamines, metiamide was added just before histamine. The samples were centrifuged $\left(1,000 \mathrm{~g}\right.$ for $10 \mathrm{~min}$ at $\left.4^{\circ} \mathrm{C}\right)$ and the media was removed. Ethanol was added to the cell pellet to extract the cAMP and the samples were centrifuged again $\left(1,000 \mathrm{~g}\right.$ for $10 \mathrm{~min}$ at $\left.4^{\circ} \mathrm{C}\right)$ and the ethanol fraction was removed and dried under nitrogen.

The cAMP concentration of PMNs was determined by the method of Brown et al. (29) and expressed as picomoles of cAMP per $10^{6}$ PMNs. The change in PMN cAMP after incubation with histamine is expressed as the percent increase as compared to base-line values.

Materials. The $\mathrm{H} 2$ antihistamine metiamide was the kind gift of Smith Kline \& French Laboratories (Philadelphia, Pa.). A 0.1-M stock solution was made by dissolving it in $1.0 \mathrm{~N} \mathrm{HCl}$ followed by $\mathrm{NaOH}$ neutralization. Histamine diphosphate was purchased from ICN Nutritional Biochemicals Div., International Chemical \& Nuclear Corp. (Cleveland, Ohio), isoproterenol from Sigma Chemical Co. (St. Louis, Mo.), theophylline from Calbiochem (San Diego, Calif.), and CB from Aldrich Chemical Co., Inc. (Milwaukee, Wis.). CB was dissolved in $0.1 \%$ dimethyl sulfoxide. At this concentration of dimethyl sulfoxide, enzyme release was not altered.

\section{RESULTS}

Enzyme release (Table II). The total concentration of the lysosomal enzyme BG was similar in PMNs both from the normal and asthma subjects. Release of BG after 30 min of incubation with autologous serum and zymosan was not significantly less in PMNs from asthmatic subjects. In addition, BG release was similar in PMNs obtained from asthma patients receiving bronchodilators and those not having taken bronchodilators for 2 wk. A less than $4 \%$ increase in supernatant lactate dehydrogenase indicated that cell viability was maintained during these and the following incubation studies and that the release of BG was not associated with cell lysis. After the incubation procedures, greater than $95 \%$ of the PMNs excluded trypan blue.

Histamine inhibition of $B G$ release. Maximal inhibition of BG release was achieved at $100 \mu \mathrm{M}$ histamine. At this concentration the response of PMNs from asthma (Table III) and control (Table IV) subjects was similar. However, at concentrations of histamine 10-0.1 $\mu \mathrm{M}$, the inhibition of lysosomal enzyme release was significantly less in PMNs of asthmatic subjects. The response to histamine in asthma was reduced approximately by a factor of 100 . The decreased granulocyte response to histamine found in asthma was not affected by bronchodilator treatment and was similar in patients whether or not they required bronchodilator therapy. The results are summarized in Fig. 1.

cAMP response to histamine (Fig. 2). The PMN cAMP response to histamine was measured and com-

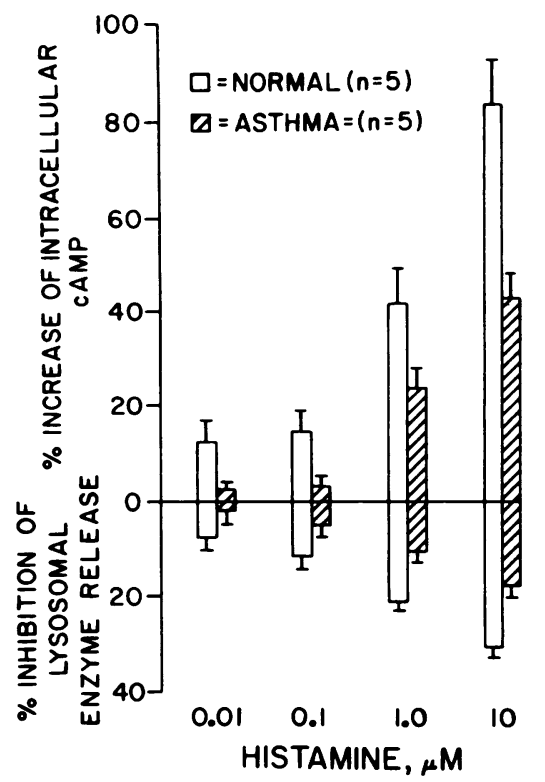

FIGURE 2 Comparison of percent inhibition of BG release by histamine and cAMP concentrations in PMNs from normal and asthma subjects. Percent inhibition of lysosomal enzyme release is calculated by comparing the enzyme release after exposure to serum-activated zymosan particles of histamine-treated to untreated PMNs. Base-line concentrations of cAMP were similar in normal $(1.25$ $\left.\pm 0.13 \mathrm{pmol} / 10^{6} \mathrm{PMNs}\right)$ and asthma $\left(1.23 \pm 0.21 \mathrm{pmol} / 10^{6}\right.$ PMNs). The increase in cAMP is determined by comparing the concentration of the cAMP in untreated to histaminetreated cells. All studies were performed in the presence of theophylline $(0.5 \mathrm{mM})$. Values are expressed as mean \pm SEM. The difference between normal and asthma at all concentrations tested was significant $(P<0.05)$. 


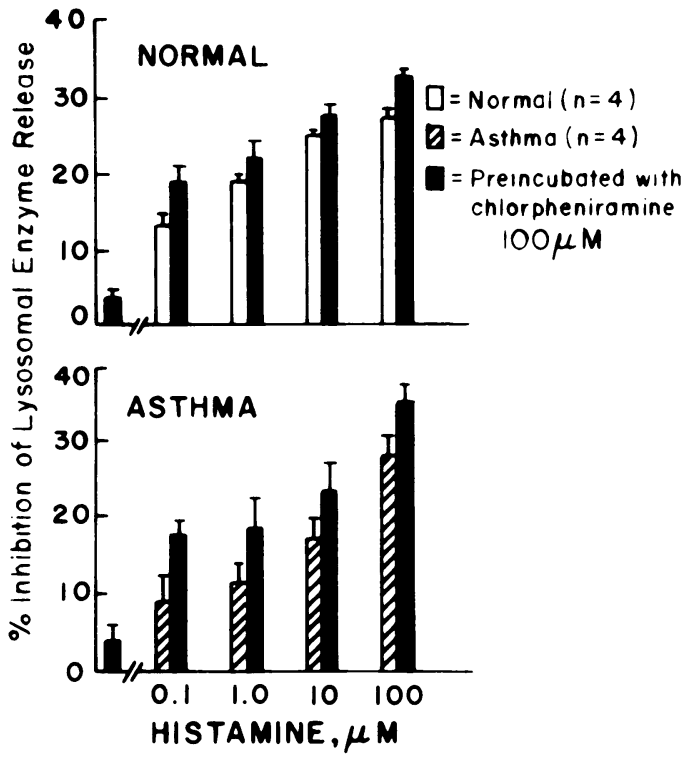

Figure 3 Comparison of the effect of the $\mathrm{Hl}$ antihistamine, chlorpheniramine, on histamine inhibition of granulocyte release of BG in normal and asthma subjects. PMNs $\left(3 \times 10^{6} / \mathrm{ml}\right)$ were treated with $\mathrm{CB}(5 \mu \mathrm{g} / \mathrm{ml})$ for $5 \mathrm{~min}$ and theophylline $(0.5 \mathrm{mM})$ for $15 \mathrm{~min}$. The $\mathrm{Hl}$ antihistamine chlorpheniramine $(100 \mu \mathrm{M})$ was added immediately before histamine and the cells incubated for an additional 15 min. The PMNs were then incubated with serum and zymosan for $30 \mathrm{~min}$. Values are the mean $\pm S E M$ of four experiments with granulocytes from normal and asthma subjects.

pared to histamine inhibition of BG release in five additional subjects with asthma (patients 11-15) and five additional controls (subjects 25-29). At histamine concentrations of $0.01-10 \mu \mathrm{M}$ the inhibition of lysosomal enzyme release was again significantly less in asthma. Histamine stimulation of cAMP was also reduced in asthma and paralleled the effects of histamine on BG release. Base-line concentrations of cAMP were similar in the PMNs from normal $(1.25 \pm 0.13$ $\left.\mathrm{pmol} / 10^{6} \mathrm{PMNs}\right)$ and asthma (1.23 $\pm 0.21 \mathrm{pmol} / 10^{6}$ PMNs) subjects.

Effect of antihistamines on histamine inhibition of $B G$ release. The PMNs from four normal and asthma subjects (patients 4, 9, 10, and 12) were treated with the $\mathrm{Hl}$ antihistamine chlorpheniramine and the $\mathrm{H} 2$ antihistamine metiamide. At $100 \mu \mathrm{M}$ chlorpheniramine alone had a small but consistent effect to inhibit the release of BG from PMNs after contact with serum-activated zymosan and also a small but consistent enhancement of histamine inhibition of enzyme release. However, chlorpheniramine did not block the histamine inhibition of lysosomal enzyme release (Fig. 3). Conversely, $100 \mu \mathrm{M}$ metiamide slightly enhanced enzyme release and blocked the inhibitory effect of histamine (Fig. 4). There was no apparent difference in the effect of the histamine antagonists on the normal and asthmatic cells.

H2 antihistamine effect on the histamine increase of PMN cAMP (Fig. 5). In PMNs from the same four normal subjects and four subjects with asthma studied above, the cAMP response to histamine was determined. Again base-line concentrations of cAMP were similar in PMNs from normal and asthma subjects $\left(1.22 \pm 0.15 \mathrm{pmol} / 10^{6} \mathrm{PMNs}\right.$ vs. $1.03 \pm 0.16 \mathrm{pmol} / 10^{6}$ $\mathrm{PMN}$, respectively, mean $\pm \mathrm{SEM})$. As noted previously, the cAMP response to histamine was significantly less in asthma $(P<0.05)$. When PMNs were incubated in the presence of increasing concentrations of metiamide, the cAMP response to histamine was reduced and then completely blocked at equimolar concentrations of two agents. Metiamide alone produced a slight increase in CAMP concentrations in PMNs from both normal and asthma subjects. An increase in granulocyte cAMP after incubation with metiamide was accompanied by an enhanced enzyme release. This is paradoxical in comparison to the previous findings (Fig. 2) where a cAMP increase paralleled an inhibition of enzyme release.

The effect of propranolol on histamine inhibition of enzyme release (Table V). PMNs were incubated with the beta-adrenergic antagonist propranolol. In the three subjects tested, the response to isoproterenol was blocked, but propranolol had no effect on histamine inhibition of $B G$ release.

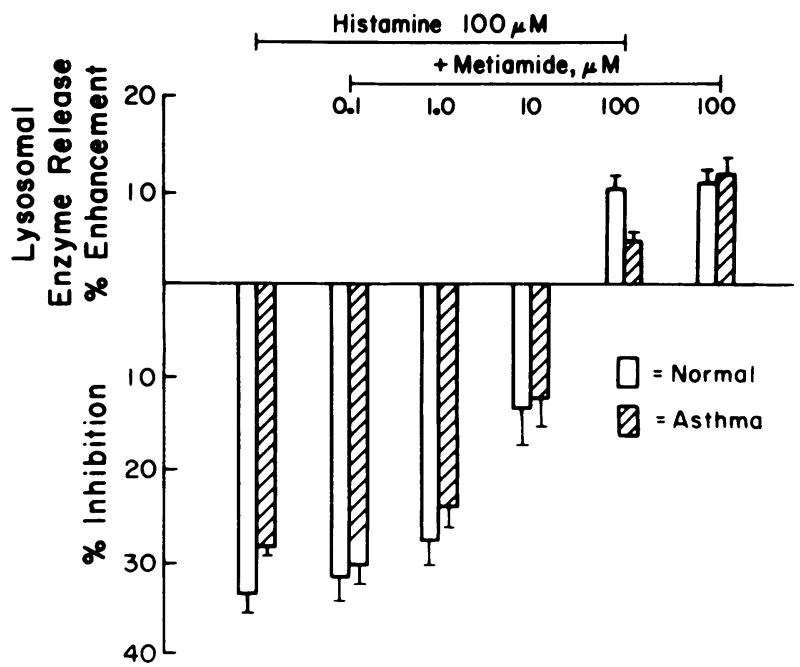

FigurE 4 Comparison of the effect of the $\mathrm{H} 2$ antihistamine metiamide on the inhibition of BG release from granulocytes by zymosan. PMNs were treated with CB $(5 \mu \mathrm{g} / \mathrm{ml}$ for $5 \mathrm{~min})$ and then theophylline $(0.5 \mathrm{mM}$ for $15 \mathrm{~min})$ and then metiamide was added immediately before the histamine. After $15 \mathrm{~min}$ incubation with histamine, the PMNs were exposed to serum and zymosan. Values are the mean $\pm S E M$ of four paired experiments with granulocytes from normal and asthma subjects. 


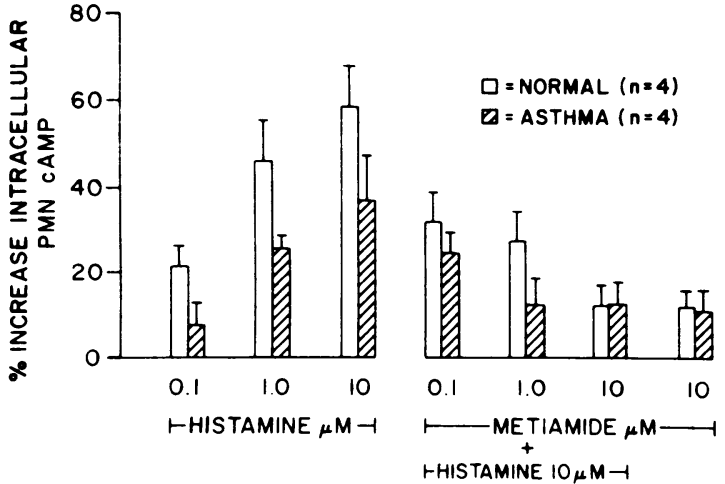

FIgURE 5 Comparison of PMN cAMP increase by histamine in the presence of metiamide in normal and asthma subjects. PMNs $\left(3 \times 10^{6} / \mathrm{ml}\right)$ were incubated with theophylline ( $0.05 \mathrm{mM}$ for $15 \mathrm{~min}$ ) before treatment with histamine ( $15 \mathrm{~min})$. In the studies with metiamide, it was added immediately before histamine. Values are the mean $\pm S E M$ of experiments with granulocytes from four normal and four asthma subjects. Base-line concentrations of cAMP were similar in normal ( $\left.1.22 \pm 0.15 \mathrm{pmol} / 10^{6} \mathrm{PMNs}\right)$ and asthma (1.03 \pm 0.16 $\left.\mathrm{pmol} / 10^{6} \mathrm{PMNs}\right)$.

\section{DISCUSSION}

Our data demonstrate a decreased $\mathrm{H} 2$ receptor response of granulocytes in asthma. This abnormality was found in both the PMN cAMP response and inhibition of zymosan-stimulated release of a lysosomal enzyme. In contrast to our observations, Gillespie et al. (13) found the lymphocyte cAMP response to histamine was normal in asthma. There are a number of possible explanations for this difference. First, lymphocytes are not a homogeneous cell population, like granulocytes, and the response of subpopulations of lymphocytes to some agonists is different (30). Comparison of the lymphocyte subpopulation response was not examined. Second, the concentrations of histamine used by Gillespie et al. were in general higher ( $10 \mathrm{mM}, 0.1 \mathrm{mM}$, and $0.001 \mathrm{mM}$ ) than we employed. It is a possibility that differences in histamine response are only apparent at lower concentrations. Third, it is also possible that this $\mathrm{H} 2$ receptor defect is not a generalized defect on all cells, but is only seen in some cell types such as the granulocytes. It is also important to indicate that this defect in granulocyte $\mathrm{H} 2$ receptor response in asthma is not absolute and represents only diminished response.

A decreased granulocyte response to histamine was found in 15 patients with asthma selected for study. It is also important to indicate that the diminished response was present to a variable degree within this asthma population as presented in Table III. From our observations it was not apparent that the defect was more pronounced in those subjects with more severe asthma or in those receiving bronchodilator therapy. There was also a degree of variability in the granulo- cyte response to histamine in individual subjects when studied on more than one occasion and was seen in the response of the granulocyte to histamine as measured by an increase in cAMP and inhibition of enzyme release in the different experiments with the same subjects. The variable response was found in both the normal and asthma population. However, the individual response to histamine was similar on the separate occasions.

The mechanism of the $\mathrm{H} 2$ defect of granulocytes in asthma is unknown. B. pertussis-vaccinated mice have a hypersensitive response to histamine and other mediators of anaphylaxis (5). Szentivanyi et al. (6) found that the vaccinated mice also have a diminished response to beta-adrenergic agonists. From these observations, Szentivanyi proposed that the hyperirritability of airways in asthma might be explained by a decreased response to beta-adrenergic stimulation (7). The concept that an increase in airway irritability is due to beta-adrenergic blockade received support from the observation of McNeill that the beta-blocking drug propranolol, caused acute bronchoconstriction in asthmatic subjects (31). However, propranolol has no effect on the airway responses of normal subjects to histamine or cholinergic aerosols (32). Similarly we found that pretreatment of normal PMNs with propranolol did not alter the response to histamine. From this observation it seems reasonable to conclude that the mechanism contributing to a decreased $\mathrm{H} 2$ granulocyte response is not produced by beta-adrenergic blockade.

The role of the $\mathrm{H} 2$ histamine receptor in the lung is not clear. Eyre has found that histamine produces relaxation of terminal bronchus of sheep and this is a $\mathrm{H} 2$ receptor response (33). However, in humans hista-

TABLE V

The Effect of Propranolol on Isoproterenol and Histamine Inhibition of Lysosomal Enzyme Release from Granulocytes with Zymosan

\begin{tabular}{|c|c|c|}
\hline \multicolumn{3}{|c|}{ Inhibition* } \\
\hline \multirow[b]{2}{*}{ Isoproterenol, $10 \mu \mathrm{M}$} & \multicolumn{2}{|c|}{ Histamine, $\mu .11$} \\
\hline & 0.1 & 10) \\
\hline \multicolumn{3}{|c|}{ ?c } \\
\hline 30.7 & 19.1 & 30.6 \\
\hline \multicolumn{3}{|c|}{ Preincubated with propranolol, $10 \mu \mathrm{M} \ddagger$} \\
\hline 6.3 & 17.0 & 31.6 \\
\hline
\end{tabular}

* All values are the mean of three experiments.

$\$$ The PMNs $\left(3 \times 10^{6} / \mathrm{ml}\right)$ were treated with CB $(5 \mu \mathrm{g} / \mathrm{ml}$ for $5 \mathrm{~min}$ ), theophylline ( $0.5 \mathrm{mM}$ for $15 \mathrm{~min})$, and propranolol (15 $\mathrm{min}$ ) before the addition of isoproterenol $(15 \mathrm{~min}$ ) or histamine ( $15 \mathrm{~min}$ ), before the addition of autologous serum and zymosan. 
mine will contract both the large and small airways in both normals and asthmatics (34). These are H1 receptor responses. Mathe et al. examined the cAMP and cyclic GMP response of sensitized guinea pig lung tissue to histamine (35). Histamine increased the levels of cAMP and also to a lesser extent cyclic GMP. Pretreatment with burimamide abolished the histamine-stimulated rise of cAMP and a $\mathrm{Hl}$ antihistamine diminished the effect of histamine on cyclic GMP levels. While these observations were made on whole lung preparations, it is tempting to speculate that airways have both $\mathrm{H} 1$ and $\mathrm{H} 2$ receptors with the former being predominant. Stimulation of the H1 would lead to constriction and $\mathrm{H} 2$ stimulation might lead to relaxation. A decrease, therefore, in the $\mathrm{H} 2$ receptor would possibly enhance the $\mathrm{H} 1$ response, and in asthma this would lead to enhanced airway constriction. Asthma subjects have a 100 -fold increase in airways sensitivity to histamine as compared to normal subjects. In asthma the decrease in $\mathrm{H} 2$ response of the granulocyte is likewise about 100-fold.

The clinical significance of this observation may also assume relevance in the role histamine plays in modulating the inflammatory response. Histamine and the other mediators of immediate hypersensitivity are released from sensitized mast cells and basophils upon specific antigen challenge. In addition to its role as mediator of the anaphylactic reaction, histamine inhibits the in vitro antigen-induced release of histamine from leukocytes of allergic individuals (36). This is a $\mathrm{H} 2$ receptor response (37). If the defect in $\mathrm{H} 2$ receptor is generalized and found on mast cells and basophils in asthma, this could lead to an enhanced release of histamine.

Airway obstruction in asthma occurs not only from bronchial muscle contraction but also inflammatory changes in the bronchi. Granulocytes are found in the bronchial wall in individuals with mucosal edema and inflammation. A prime mediator of the inflammatory response is the lysosomal enzymes from granulocytes. A decrease in histamine inhibition of lysosomal enzyme release may be playing some factor in this bronchial inflammatory response.

\section{ACKNOWLEDGMENTS}

The technical help of Ms. Marjorie Crandall and Mr. William Cooper is acknowledged.

This study was aided in part by grants from the National Institute of Health (2-R01-AI-08106 and 2-P15-AI-10404) and in part by a General Research Support grant to the University of Wisconsin Medical School from the National Institutes of Health, Division of Research Facilities and Resources.

\section{REFERENCES}

1. Curry, J. J. 1947. Comparative action of acetyl-betamethyl choline and histamine on the respiratory tract in normals, patients with hay fever, and subjects with bronchial asthma. J. Clin. Invest. 26: 430-438.

2. Parker, C. D., R. E. Bilbo, and C. E. Reed. 1965. Methacholine as a test for bronchial asthma. Arch. Intern. Med. 115: 452-458.

3. Mathe, A. A., P. Hedqvist, A. Holmgren, and N. Svanborg. 1972. Prostaglandin F2 $\alpha$ : Effect on airway conductance in healthy subjects and patients with bronchial asthma. Adv. Biosci. 9: 241-245.

4. Simonsson, B. G., F. M. Jacobs, and J. A. Nadel. 1967. Mechanisms of changes in airway size during inhalation of various substance in asthmatics. Role of autonomic nervous system. Am. Rev. Respir. Dis. 95: 873-874.

5. Kind, L. S. 1958. The altered reactivity of mice after innoculation with Bordetella Pertussis vaccine. Bacteriol. Rev. 22: 173-182.

6. Szentivanyi, A., C. W. Fischel, and D. W. Talmage. 1963. Adrenalin mediation of histamine and serotonin hyperglycemia in normal mice and the absence of adrenalineinduced hyperglycemia in Pertussis-sensitized mice. J. Infect. Dis. 113: 86-98.

7. Szentivanyi, A. 1968. The beta-adrenergic theory of the atopic abnormality in asthma. J. Allergy. 42: 203-232.

8. Lockey, S. D., Jr., J. A. Glennon, and C. E. Reed. 1967. Comparison of some metabolic responses in normal and asthmatic subjects to epinephrine and glucagon. $J$. Allergy. 40: 349-354.

9. Logsdon, P. J., E Middleton, Jr., and R. G. Coffey. 1972. Stimulation of leukocyte adenyl cyclase by hydrocortisone and isoproterenol in asthmatic and nonasthmatic subjects. J. Allergy Clin. Immunol. 50: 4556.

10. Kirkpatrick, C. H., and C. Keller. 1967. Impaired responsiveness to epinephrine in asthma. Am. Rev. Respir. Dis. 96: 692-699.

11. Middleton, E., Jr., and S. R. Finke. 1968. Metabolic response to epinephrine in bronchial asthma. J. Allergy. 42: 288-299.

12. Parker, C. W., and J. W. Smith. 1973. Alterations in cyclic adenosine monophosphate metabolism in human bronchial asthma. I. Leukocyte responsiveness to $\beta$ adrenergic agents. J. Clin. Invest. 52: 48-59.

13. Gillespie, E., M. D. Valentine, and L. M. Lichtenstein. 1974. Cyclic AMP metabolism in asthma: Studies with leukocytes and lymphocytes. J. Allergy Clin. Immunol. 53: 27-33.

14. Ash, A. S. F., and H. O. Schild. 1966. Receptors mediating some actions of histamine. Br. J. Pharmacol. 27: 427-439.

15. Black, J. W., W. A. M. Duncan, C. J. Durant, C. R. Ganellin, and E. M. Parsons. 1972. Definition and antagonism of histamine H2-receptors. Nature (Lond.). 236: 385-390.

16. Busse, W. W. 1975. Inpaired beta-adrenergic inhibition of lysosomal enzyme release from neutrophils in asthma. Clin. Res. 23: 502A. (Abstr.)

17. Henson, P. M. 1971. The immunologic release of constituents from neutrophil leukocytes. I. The role of antibody and complement on nonphagocytosable surfaces or phagocytosable particles. J. Immunol. 107: 1535- 1546.

18. Weissmann, G., R. B. Zurier, P. J. Spieler, and I. M. Goldstein. 1971. Mechanisms of lysosomal enzyme release from leukocytes exposed to immune complexes and other particles. J. Exp. Med. 134: 149s-165s.

19. Ignarro, L. J., and C. Colombo. 1973. Enzyme release from polymorphonuclear leukocyte lysosomes: Regulation by autonomic drugs and cyclic nucleotides. Science (Wash. D. C.). 180: 1181-1183. 
20. Zurier, R. B., G. Weissmann, S. Hoffstein, S. Kammerman, and H. H. Tai. 1974. Mechanisms of lysosomal enzyme release from human leukocytes. II. Effects of cAMP and cGMP, autonomic agonists, and agents which affect microtubule function. J. Clin. Invest. 53: 297-309.

21. Sullivan, T. J., K. L. Parker, S. A. Eisen, and C. W. Parker. 1975. Modulation of cyclic AMP in purified rat mast cells. II. Studies on the relationship between intracellular cyclic AMP concentrations and histamine release. J. Immunol. 114: 1480-1485.

22. Lichtenstein, L. M., and S. Margolis. 1968. Histamine release in vitro: Inhibition by catecholamines and methylaxnthines. Science (Wash. D. C.). 161: 902-904.

23. Kaliner, M. S., R. P. Orange, and K. F. Austen. 1972. Immunological release of histamine and slow reacting substance of anaphylaxis from human lung. IV. Enhancement by cholinergic and alpha adrenergic stimulation. J. Exp. Med. 136: 556-567.

24. Busse, W. W., and J. Sosman. 1976. Histamine inhibition of neutrophil lysosomal enzyme release: A H2 histamine receptor response. Science (Wash. D. C.). 194: 737-783.

25. Böyum, A. 1968. Isolation of mononuclear cells and granulocytes from human blood. Scand. J. Clin. Lab. Invest. 21 (Suppl. 97): 77-89.

26. Zurier, R. B., S. Hoffstein, and G. Weissmann. 1973. Cytochalasin B: Effect on lysosomal enzyme release from human leukocytes. Proc. Natl. Acad. Sci. U. S. A. 70: $844-848$.

27. Fishman, W. H., K. Kato, C. L. Anstiss, and S. Green. 1967. Human serum $\beta$-glucuronidase: Its measurement and some of its properties. Clin. Chim. Acta. 15: 435447.
28. Cabaud, P. G., and F. Wróblewski. 1958. Colorimetric measurement of lactic dehydrogenase activity of body fluids. Am. J. Clin. Pathol. 30: 234-236.

29. Brown, B. L., J. D. M. Albano, R. P. Ekins, A. H. Sgerzi, and W. Tampion. 1971. A simple and sensitive saturation assay for the measurement of adenosine $3^{\prime}: 5^{\prime}$ cyclic monophosphate. Biochem. J. 121: 561-562.

30. Bach, M-A. 1975. Differences in cyclic AMP changes after stimulation by prostaglandins and isoproterenol in lymphocyte subpopulations. J. Clin. Invest. 55: 10741081 .

31. McNeill, R. S. 1964. Effect of a $\beta$-adrenergic-blocking agent, propranolol, on asthmatics. Lancet. II: 1101-1102.

32. Zaid, G., and G. N. Beall. 1966. Bronchial response to beta-adrenergic blockade. N. Eng. J. Med. 275: 580-584.

33. Eyre, P. 1973. Histamine $\mathrm{H}^{2}$-receptors in the sheep bronchus and cat trachea: The action of burimamide. $B r$. J. Pharmacol. 48: 321-323.

34. Newball, H. H., and H. R. Keiser. 1973. Relative effects of bradykinin and histamine on the respiratory system of man. J. Appl. Physiol. 35: 552-556.

35. Mathé, A. A., L. Volicer, and S. K. Puri. 1974. Effect of anaphylaxis and histamine, pyrilamine, and burimamide on levels of cyclic AMP and cyclic GMP in guineapig lung. Res. Commun. Chem. Pathol. Pharmacol. 8: $635-651$.

36. Bourne, H. R., K. L. Melmon, and L. M. Lichtenstein. 1971. Histamine augments leukocyte adenosine 3'5monophosphate and blocks antigenic histamine release. Science (Wash. D. C.). 173: 743-745.

37. Lichtenstein, L. M., and E. Gillespie. 1973. Inhibition of histamine release by histamine controlled by $\mathrm{H} 2$ receptor. Nature (Lond.). 244: 287-288. 